\title{
PENGARUH FILM INDIE (INDEPENDENT) TERHADAP KETERAMPILAN MENULIS CERPEN SISWA KELAS XI SMA NEGERI 1 TALANG KELAPA
}

\author{
Juaidah Agustina dan Mardiana \\ (Dosen dan Mahasiswa Universitas PGRI Palembang) \\ Email:dmardiana582@gmail.com
}

\begin{abstract}
Abstrak- Penelitian ini bertujuan mengembangkan keterampilan menulis cerpen siswa kelas XI SMA Negeri 1 Talang Kelapa menggunakan media pembelajaran film indie (independent). Melalui metode kuantitatif dengan teknik simple random sampling peneliti dapat membedakan kelas eksperimen dan kelas kontrol. Populasi penelitian ini adalah seluruh siswa kelas XI IPS SMA Negeri 1 Talang Kelapa yang berjumlah 123 siswa. Dengan sampel kelas XI IPS 4 sebagai kelas eksperimen dan XI IPS 1 sebagai kelas kontrol yang jumlahnya sama 30 siswa. Teknik pengumpulan data menggunakan teknik tes dan dokumentasi. Teknik analisis data menggunakan Uji-t. Berdasarkan analisis data mengenai hasil belajar siswa melalui Uji-t maka diperoleh nilai $t_{\text {hitung }}=3,67$ sedangkan $t_{\text {tabel }}=1,67$. Dari hasil perhitungan didapat bahwa $t_{\text {nitung }} \geq t_{\text {tabel }}$ maka Ha diterima dengan nilai rata-rata kelas eksperimen 77,16 dan kelas kontrol 66,43 . Dengan demikian hipotesis yang penulis kemukakan yaitu "Terdapat pengaruh film indie (independent) terhadap keterampilan menulis cerpen siswa kelas XI SMA Negeri 1 Talang Kelapa" terbukti kebenarannya.
\end{abstract}

\section{Kata kunci: Media Film Indie (Independent), Menulis Cerpen.}

Abstract-This study aims to develop short story writing skills of class XI students of SMA Negeri 1 Talang Kelapa using indie film learning media (independent). Through quantitative methods with simple random sampling techniques researchers can distinguish between the experimental class and the control class. The population of this study was all students of class XI IPS SMA Negeri 1 Talang Kelapa, totaling 123 students. With a sample of class XI IPS 4 as an experimental class and XI IPS 1 as a control class with the same number of 30 students. Data collection techniques using test and documentation techniques. Data analysis techniques using the t-test. Based on data analysis regarding student learning outcomes through the $t$-test, the value of tcount $=3.67$, while ttable $=1.67$. From the calculation results, it is obtained that tcount $\geq$ ttable then $\mathrm{Ha}$ is accepted with an average value of 77,16 experimental class and 66,43 control class. Thus the hypothesis that the authors put forward that "There is an influence of indie film (independent) on the short story writing skills of class XI students of SMA Negeri 1 Talang Kelapa" is proven true.

Keywords: Indie Film Media (Independent), Short Story Writing .

\section{PENDAHULUAN}

Media adalah segala sesuatu yang dapat digunakan untuk menyalurkan pesan yang dapat merangsang pikiran, membangkitkan semangat, perhatian, dan kemauan siswa sehingga dapat mendorong terjadinya proses pembelajaran pada diri siswa. media pembelajaran dapat dikelompokkan ke dalam empat kelompok, yaitu sebagai berikut.

(1) Media hasil teknologi cetak.

(2) Media hasil teknologi audio-visual.

(3) Media hasil teknologi yang berdasarkan komputer.

(4) Media hasil gabungan teknologi cetak dan komputer.

Arsyad menyatakan bahwa Film dan vidio merupakan gambar-gambar dalam frame 
demi frame diproyeksikan melalui lensa proyektor secara mekanis sehingga pada layar terlihat gambar itu hidup. film indie adalah film yang diproduksi dengan biaya yang relatif lebih murah dari pada film cerita panjang. Film indie memberikan ruang gerak ekspresi yang lebih luas kepada para sineas dalam bereksperimentasi secara idialis. Karakteristik film indie yang pertama, secara teknis berdurasi pendek yaitu di bawah 50 menit. Namun, Garin Nugroho (dikutip Trianton, 2013:42) membatasi durasi film pendek kurang dari 30 menit. Inilah yang mengidentifikasi film indie sebagai film pendek.

Kedua, independent yaitu bebas dari tekanan. Indipendent adalah ketika seseorang membuat film karena keiginan yang besar untuk membuat film, bukan karena ingin mendapatkan uang, prestasi atau popularitas. Keinginan bekarya haruslah menjadi penyebab utama, bukan yang lainnya. Kemudian, dijiwai semangat berkarya. Film-film indie hanya akan diproduksi oleh sineas (pembuat film) yang memiliki semangat yang tinggi untuk terus berkarya. Sebab film jenis ini jauh dari kepentingan komersial. Hanya yang semangatlah yang mampu bertahan untuk terus mengembangkan produksi film indie.

Menurut Artati, menulis adalah melahirkan pikiran atau perasaan seperti mengarang, dan membuat surat. Selain itu menulis dapat diartikan sebagai proses keterampilan menuangkan pikiran dengan bahasa tulis yang tertata.
Cerpen adalah cerita yang menurut wujud fisiknya berbentuk pendek. Ukuran panjang pendeknya suatu cerita memang relatif. Namun, pada umumnya cerita pendek merupakan cerita yang habis dibaca sekitar sepuluh menit atau setengah jam. Jumlah katannya sekitar 500 hingga 5000 kata. Oleh karena itu, cerita pendek sering diungkapkan sebagai cerita yang dapat dibaca dalam sekali duduk. Nilai-nilai dalam cerpen dibagi dalam beberapa bagian yaitu sebagai berikut.

a) Nilai-nilai budaya berkaitan dengan pemikiran, kebiasaan, dan hasil karya cipta manusia.

b) Nilai-nilai sosial berkaitan dengan tata laku hubungan antara sesama manusia (kemasyarakatan).

c) Nilai-nilai moral berkaitan dengan perbuatan baik dan buruk yang menjadi dasar kehidupan manusia dan masyarakatnya.

Menurut Kosasih unsur-unsur pembangun cerpen adalah sebagai berikut.

a) Alur

Alur atau plot merupakan pola pengembangan cerita yang terbentuk oleh hubungan sebab akibat. Secara umum, alur terbagi ke dalam beberapa bagian antara lain sebagai berikut.

a. Pengenalan situasi cerita (exposition).

Dalam bagian ini, pengarang memperkenalkan para tokoh, penata adegan, dan hubungan antar tokoh.

b. Pengungkapan peristiwa (complication). 
Dalam bagian ini, disajikan peristiwa awal yang menimbul kan berbagai masalah, pertentangan, ataupun kesukarankesukaran bagi para tokohnya.

c. Menuju pada adanya konflik (rising action). Terjadi peningkatan perhatian kegembiraan, kehebohan, ataupun keterlibatan berbagai situasi yang menyebabkan bertambahnya kesukaran tokoh.

d. Puncak konflik (turning point).

Bagian ini disebut juga dengan klimaks. Inilah bagian cerita yang paling besar dan mendebarkan. Pada bagian ini pula, ditentukannya perubahan nasib beberapa tokohnya. Misalnya, apakah dia berhasil menyelesaikan masalahnya atau gagal.

e. Penyelesaian (ending).

Sebagai akhir cerita, pada bagian ini berisi penjelasan tentang nasib-nasib yang dialami tokohnya setelah mengalami peristiwa puncak itu. Namun ada pula cerpen yang penyelesaian akhir ceritanya itu diserahkan kepada imajinasi pembaca.

b) Penokohan

Penokohan merupakan cara pengarang menggambarkan karakter tokohtokoh dalam cerita. Berikut adalah contohcontoh teknik menggambarkan karakteristik tokoh.

a. Teknik analitik atau penggambaran langsung.

b. Penggambaran fisik dan prilaku tokoh.

c. Penggambaran lingkungan kehidupan tokoh.

d. Penggambaran tata kebahasaan tokoh.

e. Pengungkapan jalan pikiran tokoh.

c) Latar

Latar atau setting merupakan tempat dan waktu berlangsungnya kejadian dalam cerita. Latar berfungsi untuk memperkuat atau mempertegas keyakinan pembaca terhadap jalannya cerita ataupun pada karakter tokoh. Dengan demikian apabila pembaca sudah menerima latar itu sebagai sesuatu yang benar adanya, maka cenderung dia pun akan lebih siap dalam menerima karakter tokoh ataupun kejadian-kejadian yang berada dalam cerita itu. Menurut Kosasih, latar terbagi dalam beberapa macam yaitu:

1) Latar tempat

Tempat berlangsungnya cerita mungkin daerah yang luas, seperti nama daerah atau negara, mungkin pula berada di daerah yang sempit, seperti kelas atau pojok rumah.

2) Latar waktu

Waktu berlangsungnya cerita, mungkin pada pagi hari, malam hari, dan waktu-waktu lainnya. Seperti halnya latar tempat, pengambarannya dapat secara langsung oleh pengarang ataupun melalui penuturan tokoh. d) Tema

Tema adalah gagasan yang menjalin struktur isi cerita. Tema suatu cerita menyangkut segala persoalan, baik itu berupa masalah kemanusiaan, kekuasaan, kasih sayang, kecemburuan dan sebagainya.Tema jarang dituliskan secara tersurat oleh pengarangnya.

Untuk dapat menyingkap tema suatu cerpen, seorang pembaca harus terlebih dahulu mengenali unsur-unsur intrinsik yang dipakai oleh pengarang untuk mengembangkan cerita fisiknya.

Beberapa unsur intrinsik yang di pergunakan pengarang untuk menyalurkan tema ceritanya yaitu: alur, penokohan dan bahasa pengarang.

1) Melalui alur cerita 
Alur cerita kerapkali dipakai oleh pengarang untuk membimbing pembaca mengenali tema dalam cerita yang ditulisnya. Jika anda mendaftar peristiwa yang ada dalam cerita yang kita baca, anda akan menemukan peristiwa-peristiwa yang diurutkan atas dasar sebab akibat, yaitu peristiwa A mengakibatkan peristiwa $B$, peristiwa $B$ merupakan akibat dari peristiwa A. Rangkaian peristiwa dalam suatu cerita yang berhubungan atas dasar sebab akibat itu disebut alur.

2) Melalui tokoh cerita

Selain alur, penokohan juga biasa dipakai oleh pengarang untuk menyalurkan tema. Penokohan meliputi peran dan sifat-sifat tokoh yang diciptakan oleh pengarang. Tokoh cerita dengan bermacam-macam sifat dan wataknya sengaja diciptakan oleh pengarang untuk dimuati tema. Toko jahat (antagonis) biasanya dipertentangkan dengan tokoh baik (protagonis). Jika pengarang hendak menunjukkan kepada pembaca, bahwa kebaikan tidak selamanya benar, pengarang dapat saja mengalahkan pemain dengan watak baik. Akan tetapi, jika pengarang bertujuan menyatakan bahwa kejahatan pasti punah, pengarang tentu akan memenangkan tokoh protagonis.

3) Melalui perkataan yang dipergunakan pengarang

Perkataan dapat dipakai untuk menemukan tema. Melalui kalimat-kalimat, dialog yang diucapkan oleh tokoh-tokoh cerita, dan juga komentar pengarang terhadap peristiwa-peristiwa, pengarang dapat menyampaikan pernyataan-pernyataan yang dapat kita jadikan rumusan tema. e) Amanat

Amanat merupakan ajaran moral atau pesan didaktis yang hendak pengarang kepada pembaca melalui karyanya itu. Amanat tersirat di balik kata-kata yang disusun, dan juga berada dibalik tema yang diungkapkan. Karena iru, amanat selalu berhubungan dengan tema cerita itu.

\section{METODELOGI PENELITIAN}

Pada penelitian ini digunakan metode penelitian eksperimen (kuantitatif). Sugiyono menyatakan metode penelitian eksperimen dapat diartikan sebagai metode penelitian yang digunakan untuk mencari pengaruh perlakuan tertentu terhadap yang lain dalam kondisi yang terkendalikan.

Dalam penelitian ini subjek yang diambil dari populasi tertentu dikelompokkan secara keseluruhan menjadi dua kelompok eksperimen dan kelompok kontrol. Kelompok eksperimen diberikan perlakuan tertentu, lalu kedua kelompok dikenai pengukuran yang sama. Pada kelas XI IPS 4 akan diterapkan penggunaan media Film Indie (Independent) terhadap pembuatan cerpen (kelas eksperimen) dan pada kelas XI IPS 1 diterapkan sumber belajar tanpa menggunakan media Film Indie (Independent) atau mengunakan media buku dan ceramah (kelas kontrol). Teknik pengumpulan data yang digunakan adalah:

1) Tes

Menurut Indrakusuma (dikutip Arikunto, 2016:46) tes adalah suatu alat atau prosedur untuk memperoleh data-data atau keteranganketerangan yang diiginkan tentang seseorang dengan cara cepat dan tepat. Tes dalam 
penelitian ini adalah instrumen yang digunakan untuk mengumpulkan data tentang Pengaruh Film Indie (Independent) Terhadap Keterampilan Menulis Cerpen Siswa Kelas XI di SMA Negeri 1 Talang Kelapa Kabupaten Banyuasin, sebelum tes diberikan siswa terlebih dahulu mengikuti pelajaran pokok bahasan mengenai menulis cerpen, evaluasi dalam penelitian ini menggunakan 1 soal essay yang berstruktur.

2) Dokumentasi

Metode dokumentasi yaitu mencari data mengenai hal-hal atau variabel yang berupa catatan, transkrip, buku, surat kabar, majalah, prasasti, notulen rapat, legger, agenda, dan sebagainya.

Sugiyono mengemukakan Populasi adalah wilayah generalisasi yang terdiri atas : objek atau subjek yang mempunyai kualitas dan karakteristik tertentu yang ditetapkan oleh peneliti untuk dipelajari dan kemudian ditarik kesimpulannya. Pengambilan populasi dalam penelitian ini dilakukan dengan teknik simpel random sampling yaitu pengambilan data secara acak. Populasi penelitian ini adalah seluruh siswa kelas XI IPS dengan jumlah 123 dengan jumlah laki-laki 66 dan jumlah perempuan 58 dari empat kelas.

Sampel adalah bagian dari jumlah dan karakteristik yang dimiliki oleh populasi tersebut. Pengambilan sempel dalam penelitian ini dilakukan dengan teknik simple random sampling yaitu pengambilan data secara acak tanpa memperhatikan strata yang ada dalam populasi itu. Cara demikian dilakukan bila anggota populasi dianggap homogen. Pengambilan sampel acak sederhana dapat dilakukan dengan cara undian, memilih bilangan dari daftar bilangan secara acak.

$$
\text { Pelaksanaannya dengan cara }
$$

menggundi kelas XI IPS 1 sampai dengan XI IPS 4 Hasil dari pengundian diperoleh kelas XI IPS 1 sebagai kelas kontrol dan XI IPA 4 sebagai kelas eksperimen.

\section{HASIL DAN PEMBAHASAN}

Berdasarkan tes penelitian yang dilakukan pada kelas eksperimen dan kelas kontrol di atas dapat diketahui bahwa nilai ratarata hasil tes siswa kelas eksperimen yang menerapkan media film indie (independent)lebih tinggi yaitu sebesar 77,16 dibandingkan dengan nilai rata-rata hasil tes siswa kelas kontrol yaitu sebesar 66,43 di mana kelas kontrol tidak mendapat perlakuan pembelajaran menggunakan media film indie (independent) Artinya bahwa pembelajaran menggunakan media film indie (independent) dapat mengembangkan keterampilan menulis cerpen.

\section{Tabel 1}

\section{Data Hasil Nilai Tes Siswa}

Kelas Eksperimen dan Kelas Kontrol

\begin{tabular}{|c|c|c|c|c|}
\hline \multirow{2}{*}{$\begin{array}{l}\mathrm{N} \\
\mathrm{O}\end{array}$} & \multirow{2}{*}{ Kelas } & \multicolumn{2}{|l|}{ Nilai } & \multirow{2}{*}{$\begin{array}{l}\text { Rata } \\
\text { Rata }\end{array}$} \\
\hline & & $\begin{array}{l}\text { Tertingg } \\
\text { i }\end{array}$ & $\begin{array}{l}\text { Terenda } \\
\mathrm{h}\end{array}$ & \\
\hline 1 & $\begin{array}{l}\text { Eksperime } \\
\mathrm{n}\end{array}$ & 90 & 65 & $\begin{array}{l}77,1 \\
6\end{array}$ \\
\hline 2 & Kontrol & 80 & 40 & $\begin{array}{l}66,4 \\
3\end{array}$ \\
\hline
\end{tabular}

Sumber: Pengolahan Data Primer Tahun 2018

Dapat disimpulkan bahwa penggunaan media film indie (independent) dalam proses belajar, proses perubahan yang menggunakan media film sebagai media belajar atau pembelajaran bukan hanya materi yang 
bersumber dari buku atau pendidik. Dalam penggunaannya, media pembelajaran ini merupakan cara belajar yang baru di SMA Negeri 1 Talang Kelapa pada materi menulis cerpen. Sebelum menggunakan media film indie (independent), peneliti melakukan observasi pada kelas eksperimen atau kelas yang akan diberi perlakuan. Kelas eksperimen yaitu kelas XI IPS 4 berjumlah 30 siswa dan kelas kontrol yaitu kelas XI IPS 1 berjumlah 30 siswa yang tidak diberi perlakuan atau menggunakan model konvensional yaitu metode ceramah. Penelitian ini dilakukan sebanyak dua kali pertemuan untuk setiap kelas dan pertemuan kedua merupakan tes akhir untuk kelas eksperimen maupun kelas kontrol.

Berdasarkan data hasil belajar siswa, didapat nilai rata-rata nilai hasil belajar siswa pada kelas eksperimen 77,16 . Sedangkan pada kelas kontrol 66,43 dapat diketahui nilai rata-rata eksperimen lebih besar dari kelas kontrol. Setelah mendapatkan data hasil tes siswa, maka peneliti melakukan analisis data pada tes tersebut. Analisis data dilakukan dengan menggunakan Uji-t yang terdiri dari uji normalitas data, uji homogenitas data, uji hipotesis. Uji normalitas data dilakukan untuk mengetahui normal atau tidaknya suatu penyebaran data, kemudian uji homogenitas data diperlukan untuk membuktikan persamaan varians kelompok yang membentuk sampel sedangkan uji hipotesis data diperlukan untuk melihat pengaruh dari dua proses belajar mengajar tersebut. Berdasarkan perhitungan yang didapat untuk kelas eksperimen uji normalitas data diperoleh $\mathrm{Km}=-0,06$ data normalitas tersebut terletak antara (-1) dan (+1). Sedangkan untuk kelas kontrol uji normalitas data diperoleh $\mathrm{Km}=-0,27$ terletak antara $(-1)$ dan $(+1)$ sehingga dapat dikatakan bahwa data kelas eksperimen dan kelas kontrol terdistribusi normal. Kemudian untuk uji homogenitas data diperoleh data $X_{\text {hitung }}^{2} 708,044$ dan $\quad X_{\text {tabel }}^{2}=\geq$ 1,67 Dengan taraf nyata $\alpha=0,95$ diperoleh $X_{\text {tabel }}^{2}=1,67$ dan $X^{2}$ hitung 708,044 diketahui syarat homogen $X^{2}$ hitung $\geq X_{\text {tabel }}^{2}$ maka didapat 708,044 $\geq$ 1,67 dan diketahui syarat homogen $X_{\text {hitung }}^{2} \geq$ $X_{\text {tabel }}^{2}$ maka didapat $708,044 \geq 1,67$. Sehingga dapat disimpulkan bahwa sampel berasal dari populasi yang sama. Jadi, penelitian ini baik kelas eksperimen maupun kelas kontrol mengikuti distribusi normal dan homogen.

Selanjutnya setelah pengujian normalitas data dan homogenitas data dilakukan, data tersebut dinyatakan terdistribusi normal dan varians dalam penelitian bersifat homogen, maka tahap berikutnya yang dilakukan adalah pengujian hipotesis penelitian dengan menggunakan statisitik parametris yaitu rumus Uji-t dengan kriteria pengujian hipotesis jika $\mathrm{Ha}$ diterima $\mathrm{t}_{\text {hitung }} \geq \mathrm{t}_{\text {tabel }}$ atau $\mathrm{t}_{\text {tabel }} \leq \mathrm{t}_{\text {hitung }}$ berarti $\mathrm{H}_{0}$ ditolak. Berdasarkan analisis data mengenai hasil belajar siswa melalui Uji-t maka diperoleh nilai $t_{\text {hitung }} \geq t_{\text {tabel }}$ atau $3.67 \geq 1,67$. Dari hasil perhitungan didapat bahwa $t_{\text {hitung }} \geq t_{\text {tabel }}$ maka Ha diterima.

Dengan demikian, kelas eksperimen yang menggunakan media film indie (independent) menunjukkan adanya pengembangan di dalam keterampilan menulis 
cerpen dibandingkan kelas kontrol yang tidak diberi perlakuan khusus. Hal tersebut diperkuat oleh Komang ia mengemukakan bahwa pengunaan film pendek dapat meningkatkan kemampuan menulis cerpen siswa. Terlihat dari 80\% dari 40 siswa memberikan respon positif dari penerapan media pembelajaran film. Adapun keterbatasan dan keuntungan film itu sendiri Keuntungan film menurut Arsyad sebagai berikut. a). Film dapat melengkapi pengalamanpengalaman dasar dari siswa ketika mereka membaca, berdiskusi, melakukan praktek, dan lain-lain. b). Film dapat menggambarkan suatu proses secara tepat yang dapat disaksikan secara berulang-ulang jika dipandang perlu. c). Di samping mendorong dan meningkatkan motivasi, film dapat menanamkan sikap dan segi-segi afektif lainnya. d). Film yang mengandung nilai-nilai positif dapat mengundang pemikiran dan pembahasan dalam kelompok siswa. e). Film dapat menyajikan peristiwa yang berbahaya bila dilihat secara langsung. f). Dengan kemampuan dan teknik pengambilan gambar frame demi frame, film yang dalam kecepatan normal memakan waktu satu minggu dapat ditampilkan dalam waktu satu atau dua menit. Arsyad mengemukakan Keterbatasannya film sebagai berikut. a). Pengadaan film umumnya memerlukan biaya cukup mahal dan memakan waktu banyak. b). Pada saat film dipertunjukkan, gambar-gambar bergerak terus sehingga tidak semua siswa mampu mengikuti informasi yang ingin disampaikan melalui film tersebut. c). Film yang tersedia tidak selalu sesuai dengan kebutuhan dan tujuan belajar yang diinginkan; kecuali film itu dirancang dan diproduksi khusus untuk kebutuhan sendiri.

Dengan demikian Penggunaan media film khususnya film indie (independent) dapat meningkatkan semangat belajar. Karena, siswa lebih aktif serta memunculkan imajinasi dan ide dalam proses belajar mengajar itu sendiri. Setelah melakukan penelitian peneliti mendapat respon positif dari guru mata pelajaran bahasa Indonesia dan siswa yang diteliti, ini dilihat dari hasil siswa itu sendiri. Dengan demikian, pembelajaran dengan media ini akan menciptakan suasana belajar yang menyenangkan sehingga peserta didik lebih memahami manfaat ilmu yang dipelajarinya. Hal tersebut disebabkan peserta didik mempraktikkan dan belajar dari pengalamannya.

\section{PENUTUP}

Berdasarkan nilai tes siswa, nilai ratarata kelas eksperimen setelah menggunakan media film indie (independent) sebesar 77,16 dibandingkan dengan nilai rata-rata siswa kelas kontrol yang tidak menggunakan media film indie (independent) sebesar 66,43 dengan selisih nilai antara kelas eksperimen dan kelas kontrol sebesar 10,73. Hipotesis penelitian yang menyatakan bahwa "Terdapat Pengaruh Film Indie (Independet) Terhadap Keterampilan Menulis Cerpen Siswa Kelas XI SMA Negeri 1 Talang Kelapa". Terbukti dari hasil perhitungan melalui Uji-t maka diperoleh nilai $t_{\text {hitung }} \geq t_{\text {trabel }}$ atau $3,67 \geq 1,67$. Dari hasil perhitungan didapat bahwa $t_{\text {hitung }} \geq t_{\text {tabel }}$ maka Ha diterima. Setelah 
melakukan penelitian peneliti mendapat respon positif dari guru mata pelajaran bahasa Indonesia dan siswa yang diteliti.

\section{DAFTAR PUSTAKA}

Arikunto, Suharsimi. 2016. Dasar-Dasar Evaluasi Pendidikan. Jakarta: Bumi Aksara.

Arsyad, Azhar. 2006. Media Pembelajaran. Jakarta: Raja Grafindo Persada.

Artati, Budi. 2007. Gemar Membaca dan Menulis. Yogyakarta: Macanan Jaya Cemerlang.

Darmawati, Uli. 2009. Ragam Bahasa Indonesia. Yogyakarta: Intan Prawira.

Daryanto. 2012. Media Pembelajaran. Bandung: Sarana Tutorial Nurani Sejahtera.

Komang, dkk. (2015). "Pengunaan Film Pendek Untuk Meningkatkan Kemampuan Menulis Cerpen Siswa Kelas IX A SMP Negeri 1 GEROKGAK", Jurnal Jurusan Pendidikan Bahasa dan Sastra Indonesi. Vol. 3. No. 1.

Kosasih, E. 2014. Dasar-Dasar Keterampilan Bersastra. Bandung: Yrama Widya.

Kosasih, E. 2008. Apresiasi Sastra Indonesia. Jakarta: Nobel Edumedia.

Kurnia. 2014. Bahan Ajar Linguistik Umum. Palembang.

Nasional, Departemen Pendidikan. 2008. Kamus Besar Bahasa Indonesia Pusat Bahasa Edisi Keempat. Jakarta: Gramedia Pustaka Utama.
Sugiyono. 2017. Metode Penelitian Pendidikan. Bandung: Alfabeta.

Susiana. (2014). "Peningkatan Kemampuan Menulis Cerpen Dengan Media Videoklip Pada Siswa Kelas IX F SMP Negeri 2 Kalitidu Bojonegoro". Jurnal Edu-Kata. Vol. 1, No. 2.

Tarigan, Henry Guntur. 2008. Menulis Sebagai Suatu Keterampilan Berbahasa. Bandung: Angkasa.

Trianton, Teguh. 2013. Film Sebagai Media Belajar. Yogyakarta: Graha IImu. 